\author{
ks. Dariusz Raś \\ Uniwersytet Papieski Jana Pawła II w Krakowie
}

\title{
MEDIA - EDUKATOR I NAUCZYCIEL WIARY. EWANGELIZACJA W ŚWIECIE EKSPOZYCJI MEDIALNYCH
}

\begin{abstract}
Media - educator and a teacher of faith. Evangelisation in the world of media exposure. The world of 'tribal digital users' known as the 'multitasking generation' or 'generation Z' makes up its world out of thousands of pieces. This does not suffice if one wants to discover the mystery of man, encounter a culture, discover a great tradition or have faith in a personal God. Some people wrongly assume that it takes just one click or the reading of 140 characters to attain knowledge information, discover the truth or get to the heart of the matter. The purpose of this text is to aid the practical discovery of the principle that, in the final analysis, the media is more of a human victory than a technological one. The use of traditional and modern media may become a means for man to deepen his own awareness and discover signs of the Creator. This kind of competence can be acquired through parental awareness, inspirational teachers, catechists and group animators. They will be inspirational through the experience of their faith in the context of the communicative gains of the latest technologies. True teaching of the faith leads to a knowledge of God and the ability to distinguish good from evil in a contemporary context. A competent teacher of faith reveals the most important values to young people: love, life, family, truth in the slight of the Gospel and does so constantly using a new language and the new tools of communication.
\end{abstract}

Media - edukator i nauczyciel wiary. Ewangelizacja w świecie ekspozycji medialnych. „Cyfrowi tubylcy” zwani pokoleniem multitasking czy „generacją Z”, składają swój świat z tysiąca puzzli. A to nie wystarczy, aby poznać tajemnicę człowieka, spotkać się z kulturą, odkryć wielkie tradycje oraz zasmakować wiary w osobowego Boga. Niektórym złudnie się wydaje, że wystarczy jeden klik i odczytanie 140 znaków, aby osiągnąć wiedzę, poznać prawdę czy dotknąć sedna sprawy. Ten 
tekst ma posłużyć praktycznemu odkryciu zasady, że media są w ostatecznym rozrachunku bardziej zdobyczą ludzką niż technologiczną. Używanie mediów tradycyjnych i nowoczesnych może stać się dla człowieka drogą do pogłębienia siebie i znalezienia śladów Stwórcy. Takie kompetencje można nabyć przy udziale świadomych rodziców, inspirujących nauczycieli, katechetów, animatorów wspólnot. Oni wskażą inspiracje płynące z doświadczenia wiary w kontekście zdobyczy komunikacyjnych najnowszej generacji. Prawdziwa nauka wiary prowadzi do poznania Boga, rozróżnienia, co dobre, a co złe w kontekście współczesnym. Kompetentny nauczyciel wiary odkrywa przed młodym wartości najdonioślejsze: miłość, życie, rodzinę, prawdę w kontekście Ewangelii, a czyni to, niejednokrotnie używając nowego języka i nowych narzędzi przekazu ${ }^{1}$.

Keywords teacher, media, faith, education, competence

nauczyciel, media, wiara, edukacja, kompetencja

W obiegowej opinii wieszczy się koniec tzw. wielkich narracji. Niektórym wydaje się, że wystarczy jeden klik i odczytanie 140 znaków, aby osiągnąć wiedzę, poznać prawdę czy dotknąć sedna sprawy. „Cyfrowi tubylcy”, zwani pokoleniem multitasking, czy „generacją Z”, składają swój świat z tysiąca puzzli. Młodzi są w stanie wykonywać parę czynności naraz i z łatwością przechodzą ze świata off line do online. Przejście po cyfrowych „drogach” to jednak zupełnie za mało, aby poznać tajemnicę człowieka, spotkać się z kulturą, tradycją czy doświadczeniem wiary. A przecież również w naszych czasach codzienność człowieka powinna przybliżyć go do Boga.

Ten tekst ma posłużyć praktycznemu odkryciu zasady, że sama komunikacja jest w ostatecznym obrachunku bardziej zdobyczą ludzką niż technologiczną. Komunikacja międzyludzka i używanie mediów mają stać się dla człowieka drogą do pogłębienia siebie i znalezienia śladów Stwórcy, a nie krzewienia ideologii czy przeżywania naskórkowej rozrywki. Jak edukować do takiej postawy? Czego potrzeba nauczycielowi wiary, duchownemu czy rodzicowi? Wydaje się, że praktyce potrzeba przynajmniej podwójnej niejako umiejętności: poznawania narzędzi komunikacji i skutecznego komunikowania z człowiekiem o wielkich wartościach. Nauczymy się wówczas w procesie kształcenia lepiej przekazywać inspiracje płynące z wiary chrześcijan, takie jak postrzeganie człowieka jako osoby, wartości życia, wartości małżeństwa i rodziny, poznawania przystających do siebie sfer sacrum i profanum ${ }^{2}$.

${ }^{1}$ Druga część niniejszego tekstu odwołuje się do wykładu Wychowanie katechizowanych do odbioru mediów, wygłoszonego przez autora podczas konferencji w Przemyślu 25 czerwca 2004 roku, w: www.katecheza. episkopat.pl/download/ Wychow_do_odbioru_mediow.doc (28.10.2017).

2 Por. Franciszek, Przekaz w stużbie autentycznej kultury spotkania. Orędzie papieża Franciszka na XLVIII Światowy Dzień Środków Społecznego Przekazu (24.01.2014), http://w2.vatican.va/content/francesco/ pl/messages/communications/documents/papa-francesco_20140124_messaggio-comunicazioni-sociali.html (30.10. 2017). 


\section{WSZĘDOBYLSKOŚĆ MEDIÓW}

Środowisko życia człowieka podlega zmianom, a sposób komunikacji międzyludzkiej zmieniał się przez wieki. Spoglądamy na ten proces również w naszym pokoleniu. Dominantą staje się nie tyle słuchanie, ile oglądanie, przyglądanie się, serfowanie, a nawet samo słyszenie, podsłuchanie, podglądanie, bycie online w sieci i na forach społecznościowych. Przekaz wielkich wartości traci na elektronicznej transmisji, a wysiłek nauczycieli wiary: rodziców, duchownych, katechetów może zmarnowaćjedna lektura tekstu w internetowej przeglądarce o znalezisku „grobu prawdziwego Jezusa” w okolicach Jerycha.

Struktura mediów XXI wieku staje się tak „polifoniczna”, że niejako wymusza na człowieku pewien rodzaj powierzchowności. Środowisko techniczne nastawia raczej na opcje, warianty, nowości, szybki przekaz. Coraz rzadziej stać nas na stałość, głębię, cierpliwe dociekanie prawdy, poszukiwanie Niewidzialnego. Ewangelia, czyli Dobra Nowina o Jezusie, wielu słuchaczom wydaje się mało atrakcyjna i niezrozumiała. Przypomina się scena z Areopagu (por. Dz 17, 22n). Paweł z Tarsu proponuje obywatelom ateńskim pełną retorycznych elementów mowę, a w niej wizję nieznanego Grekom Boga, w którym „żyjemy, poruszamy się i jesteśmy”. Jedni go wyśmiewają, inni mu odpowiadają: „posłuchamy cię o tym innym razem”, tylko niektórzy wychodzą ze struktur swojego środowiska, formuł i porządku pogańskiego świata. W innym miejscu Paweł opisuje sposób skutecznego komunikowania wiary (por. Rz 10, 17). „Otóż wiara rodzi się z tego, co się słyszy, tym zaś, co się słyszy, jest słowo Chrystusa". Klasyczna formuła św. Pawła opisuje relację: Chrystus-nauczyciel wiary-słuchacz. Nie można zapominać o tym starym kluczu i w przerażeniu stwierdzić, że to już passé.

Wiara ludzi XXI wieku nadal bierze się ze spotkania, słuchania, czytania świadectw, afirmowania, opowiadania, doświadczania. Jednak w komunikacji międzyludzkiej zdają się dominować formuły przekazu mniej bezpośrednie. Odbiorca przekazu religijnego staje jakby zagubiony w agorze mediów. Nie umie sam rozróżnić w potoku słów słowa Jezusa. Trzeba mu udzielić pomocy, ponieważ natłok informacji nie sprzyja odkrywaniu tego, co prawdziwe. Atrakcja przekazu zdaje się przerastać formą opowieść o prawdziwym Bogu. Z tego powodu na kerygmę (pierwsze głoszenie), katechezę, formację do wartości, historię biblijną czeka swoisty test na rynku mediów, który przybiera czasami kształt zderzenia światów.

Młody adresat często wybiera samotność przed ekranem. Bywa wówczas urzeczony teatrem atrakcji, wspaniałością kreacji gier i prostotą krótkich komunikatów. Odbiera w osamotnieniu pocztę elektroniczną, teksty informacyjne, obrazy filmików czy twitty społeczności. Trwa w samotności sieci. Sposobu nawiązania kontaktu z tym samotnikiem i umiejętności przerwania jego poznawczego letargu brakuje wielu ojcom i matkom, nauczycielom religii, kaznodziejom. Nauczyciel wiary staje nierzadko bezradny wobec największego autorytetu, czyli profesora Googlea. Dlatego celem niniejszego wywodu jest wskazanie takich programów edukacji medialnej, które nie tylko wykształcą w nas określone kompetencje, pozwalając na świadome korzystanie z mediów, ale również pozwolą na skuteczne zainteresowanie odbiorcy rzeczywistością wiary. 
Klasyczna narracja doktryny wiary staje się dla wielu młodych mniej atrakcyjna $z$ uwagi na godziny spędzone przed posłusznym dotykowi ekranem. Na ziemi trwa w tej chwili przede wszystkim lektura krótkich komunikatów, kolorowych informacji, mających wagę marketingową filmów, obrazów i notek. Z rzadka pojawiają się wpisane również w nowe media przystanie wiary, mądrości, wartości na miarę człowieka. Dostrzegamy nierzadko pewną nieprzystawalność pokoleń związanych z dotykowym ekranem, choć przeczuwamy intuicyjnie możliwość spotkania z każdym młodym człowiekiem.

\section{Hipertekst}

Jaskrawym przykładem opisywanej skłonności kultury medialnej do powierzchowności jest tzw. literatura hipertekstualna. Ma ona charakter nielinearny. Każda opowieść jest układanką, którą można czytać na wiele sposobów. Wiele w niej chaosu. W informatyce hipertekst oznacza sposób wzajemnego wiązania ze sobą wielu informacji za pomocą niewidzialnych linków, niezależnie od tego, czy mają charakter tekstowy, czy też obrazowy. Taki zabieg umożliwia również operowanie obrazami, filmami wideo czy animacjami ${ }^{3}$. W literaturze hipertekstualnej jednak chodzi o coś innego: czytelnik nie potrzebuje ani początku, ani końca, ani momentu wywołującego przeżycie, ani pytania: co zrobiłbym, zrobiłabym na miejscu głównego bohatera? Taka rzeczywistość wymaga od użytkownika ekranu urządzenia cyfrowego, gdzie wyświetlane są tzw. leksje, czyli niekończące się w tekście odsyłacze do innych miejsc w tekście. W tego typu literaturze autor nie jest naprawdę istotny ${ }^{4}$. Opracowuje tylko pewne ramy fabularne, które proponuje się odbiorcy. Lecz de facto odbiorca nie jest bardzo dla tej formy postpowieści istotny. Ważne jest stawanie się samoorganizującego się tekstu-obrazu.

Mike Sandbothe tak ujmuje to zjawisko: „W warunkach hipertekstu pisanie i czytanie staje się czynnością tworzenia obrazu. Piszący buduje na ekranie strukturę na kształt sieci [...]. Ten obraz ma charakter wielopostaciowy, skojarzeniowy i złożony. Składa się z różnych i licznych ścieżek oraz odesłań, które czytający formuje w indywidualne wariacyjne pismo-obrazy, wynikające ze współdziałania otwartej struktury tekstu $\mathrm{z}$ interesami i perspektywami czytającego" ${ }^{5}$.

Korzystający z hipertekstualnej literatury odbiorca nie jest ukierunkowany na porządek opowieści, ale na bezcelowe wędrowanie i pewną grę. Mozaika fabuły ma dość

${ }^{3}$ Por. Ch. Vandendorpe, Od papirusu do hipertekstu. Esej o przemianach tekstu i lektury, tłum. A. Sawisz, Warszawa 2008, s. 101-102.

${ }^{4}$ Por. M. Wądołowski, Literatura hipertekstowa - (r)ewolucja czy chaos?, http://krytyka.org/literatura-hipertekstowa-rewolucja-czy-chaos/ (3.11.2016). Dalej Wądołowski przypomina: Kamieniem milowym w historii literackiego hipertekstu była książka Laurence’a Sterne’a Życie i myśli J. W. Pana Tristrama Shandy (wydana w 1759 roku), w której autor pogwałcił wszelkie ogólnie przyjęte zasady literackie - pojawiają się w niej puste strony (do uzupełnienia przez czytelnika), łamane są zasady ortografii i interpunkcji, przedmowa znajduje się w połowie III księgi, a inwokacja na końcu. Dwudziestowieczni twórcy postmodernistyczni widzieli w Sternie prekursora swojego gatunku.

${ }^{5}$ M. Sandbothe, Transwersalne światy medialne. Filozoficzne rozważania o Internecie, tłum. K. Krzemieniowa, w: Widzieć, myśleć, być. Technologie mediów, red. A. Gwóźdź, Kraków 2011, s. 217. 
przypadkowy, samoorganizujący się charakter. Często przypomina to bezwiedne korzystanie ze środków komunikowania przez tysiące ludzi na ulicy, w domu, pracy, miejscach kultu, aucie czy kawiarni, które pomija spotkania z drugim człowiekiem, prowadząc do monologu $\mathrm{w}$ sieci, a nie do dialogu $\mathrm{z}$ osobą.

Narzędzia hipertekstualne stały się niejednokrotnie celami samymi w sobie, nawykami społecznymi, przedłużeniami marzeń sennych. Wartości społecznych, takich jak: wierność, odpowiedzialność, miłość, prawda $\mathrm{z}$ trudem można się dopatrzyć w świecie hipertekstualnych skojarzeń i powierzchownych, szybkich zdarzeń medialnych. Ta ostania forma literackiej twórczości jest rozpoznawalną cechą kakofonii przekazu współczesnego środowiska wielkich miast i małych wiosek przyłączonych siecią. Dokąd zmierzamy? Do konieczności terapii zbiorowej?

\section{3. ŚRODOWISKO E-EDUKACJI CZY HOMO TABLETIS}

W kontekście przekazu wiary chrześcijańskiej potrzeba większej świadomości rodziców, nauczycieli, duchownych o novum środowiska życia człowieka. Człowiek w sieci porusza się jak w salonie krzywych zwierciadeł. Dotyczy to zwłaszcza świadomości użytkowania mediów jako środowiska wirtualnego, a nie realnego. Elementy mediaedukacji istniejące w szkolnych programach kształcenia są niewystarczające. Intuicyjne korzystanie przez dzieci z tabletów i smartfonów pogłębia najczęściej dysfunkcje używania mediów w procesie poznawania. Ograniczenie rozwoju zmysłowego do przekazu płynącego z ekranu pozbawia najmłodszych naturalnej poznawczej drogi rozwoju. Zjawisku sprzyja brak czasu na rozmowę z najmłodszymi w rodzinach. „Kampania Mama, tata, tablet prowadzona przez Fundację Dzieci Niczyje powstała z myślą o rodzicach dzieci w wieku od 0 do 6 lat. Akcja przestrzega przed zbyt wczesnym i niekontrolowanym udostępnianiem dzieciom urządzeń elektronicznych, jak tablety czy smartfony. Autorzy kampanii wskazują jednocześnie, kiedy i jak udostępniać media elektroniczne z pożytkiem dla rozwoju najmłodszych"6.

Dane badawcze zaskakują. W 2015 roku 64 proc. dzieci w wieku od 6 miesięcy do 6,5 lat korzystało z urządzeń mobilnych, w tym 25 proc. codziennie. 26 proc. dzieci $\mathrm{w}$ tymże przedziale wiekowym miało już wtedy własne urządzenie mobilne, 79 proc. oglądało filmy, a 62 proc. grało na smartfonie lub tablecie. 69 proc. rodziców udostępnia dzieciom urządzenia mobilne, kiedy muszą zająć się własnymi sprawami; 49 proc. rodziców stosuje to jako rodzaj nagrody dla dziecka ${ }^{7}$. A przecież dla dzieci do 2 roku życia technologie informacyjno-komunikacyjne (TIK) nie są w ogóle wskazane, a potem winny być wprowadzane stopniowo i pod całkowitym nadzorem rodzicielskim.

Znikomy procent rodziców towarzyszy dziecku podczas użytkowania urządzeń sieciowych, zapominając, że wskazania pediatrów zachęcają do zupełnie innych zachowań.

\footnotetext{
${ }^{6} \mathrm{http} / /$ mamatatatablet.pl/campaign/ (21.04.2017).

7 Por. A. Bąk, Korzystanie z urządzeń mobilnych przez małe dzieci w Polsce. Wyniki badania ilościowego, Warszawa 2015, s. 2-17.
} 
Rodzice powinni troszczyć się przede wszystkim o budowanie i podtrzymywanie interakcji rówieśniczych oraz interakcji z osobami dorosłymi, sami prezentować dzieciom pozytywne wzorce i uczyć je ważnych wartości społecznych, doceniać ich twórczość, umożliwiać naukę przez obraz i dźwięk, uczyć bezpiecznego i odpowiedzialnego wykorzystania technologii, stymulować naukę pisania, rozwój mowy, rozwijać inteligencję wizualną dzieci w wieku przedszkolnym i szkolnym ${ }^{8}$. Do tych kompetencji należy również dodać naukę modlitwy. Porządek duchowy dopełnia naszego doświadczania świata i winien być prezentowany również w kontekście cyfrowym.

Papież Franciszek wskazał kiedyś na inną ciekawą obserwację bliską autorowi: „Widzieliście takich ludzi, którzy wszędzie robią tylko zdjęcia i na nic nie patrzą. Nie potrafią patrzeć. Dopiero w domu oglądają sobie zdjęcia. Ale patrzeć na coś w rzeczywistości to nie to samo, co oglądać zdjęcia. I jeśli będziemy żyć jak turyści, to będziemy patrzeć jedynie na zdjęcia albo na własne wyobrażenia o rzeczywistości. Dla młodych jest to pokusa, żyć jak turyści. Nie mam nic przeciwko turystyce, spacerowaniu tu i tam, bo to piękne. Mam tu na myśli postrzeganie życia oczami turysty, czyli powierzchownie, i robienie sobie zdjęć, by potem je oglądać. To oznacza, że nie dotykam rzeczywistości, nie patrzę na to, co się dzieje, nie widzę rzeczy takich, jakimi są"”.

Powyższy tekst uogólnia pogląd, że tak samo jako fotografia nie jest prawdą o rzeczywistości natury, tak TIK nie mogą stanowić środków pierwszorzędnych czy wręcz wyręczających $\mathrm{w}$ wychowaniu młodych, $\mathrm{w}$ tym wychowaniu do przeżywania własnej wiary. Innymi słowy sieć może jedynie przybliżyć doświadczenie wiary, ale go nie zastąpi. Niestety wielu rodziców zdaje się o tym zapominać. Technologie informacyjno-komunikacyjne niosą niewątpliwe wielkie możliwości i potencjalne korzyści wykorzystania ich w procesie e-edukacji dzieci. Ale bez uczestnictwa rodziców i wychowawców rozwój alfabetyzmu medialnego najmłodszych nie prowadzi do odpowiedzialnego i konstruktywnego wykorzystania tych instrumentów. Można powyższe rozważanie podsumować formułą: homo tabletis mówmy nie, e-edukacji mówmy tak.

\section{SZABLON POZNAWCZY}

Przeżycie doświadczenia wiary wymaga od pokolenia starszych przynajmniej podstawowych kompetencji w zakresie edukacji medialnej, w tym TIK. Teza ta łatwo może zostać poparta również w kontekście szkolnym i akademickim. Uznani badacze Eric Havelock i Marshall McLuhan ukazali, że technologie stały się jednym z najważniejszych determinantów zmieniających sposoby postrzegania i interpretowania rzeczywistości w stechnicyzowanym świecie. Internet i inne media są bowiem oknem na świat, ale i szablonem - szlabanem poznawczym. Ta konstatacja dotyczy również rzeczywistości

${ }^{8}$ Por. J. Pyżalski, M. Klichowski, M. Przybyła, Szanse i zagrożenia w obszarze wykorzystania technologii informacyjno-komunikacyjnych (TIK), ze szczególnym uwzględnieniem aplikacji mobilnych, Poznań 2014, s. 6-8.

${ }^{9}$ Papież do młodych: miejcie serce marynarza, odważne i siegające daleko, http://pl.radiovaticana.va/ news/2017/05/27/papież_do_młodych_miejcie_serce_marynarza,_odważne_i_sięgaj/1315235 (21.11.2017). 
wiary człowieka, zwłaszcza dorastającego. Teoria technologicznego determinizmu uzmysławia, iż to, jak myślimy, jest współcześnie w dużym stopniu uwarunkowane doświadczeniem technologicznym. Tak jak przestrzega się przed bezwiednym używaniem technologii komunikacyjnych w każdym wieku edukacji, tak też należy stwierdzić, że warunkiem odnalezienia się w rzeczywistości jest wprowadzenie osób w środowisko naturalne, jak i technologiczne. Doświadczenie dostępu do technologii nie przypada jednak w udziale wszystkim. Wskazuje się na mentalność archaiczno-analogową oraz jej przeciwstawia technologiczno-informacyjną ${ }^{10}$. W tym środowisku nierówności dostępu technologicznego jednakowoż głosi się wiarę. Należy jednak głosić ją z kompetencją w obydwu przypadkach.

Jakie działania więc podejmować? Pytanie o to, czy w XXI wieku wiara człowieka rzeczywiście kształtuje się nadal w oparciu o przekaz z ust do ust, jest bezzasadne. Medium podstawowym jest słowo. Homo loquens wyraża się poprzez słowa. Mowa to podstawowe uzdolnienie komunikacyjne człowieka, również w odniesieniu do Boga i człowieka. Kłopot ludzi wynika jednak z determinujących a powierzchownych przekazów docierających poprzez wiele kanałów w polifonicznym rytmie skandującym przeważnie tylko hasła i idee niemające wiele wspólnego z Ewangelią. Rodzimy się, żyjemy i umieramy w środowisku medialnym, którego oddziaływania prawie nie zauważamy. Media działają w tle. Wpośród tej medialnej kakofonii głosów niektórzy ze zdziwieniem stwierdzają, że nie widzą sensu życia, nie umieją już głęboko wierzyć i są zaskoczeni tym, że trzeba ciągle rozwijać swoje człowieczeństwo, uczyć się kochać bliskich przez lata i odkrywać własną duchowość jako doświadczenie głęboko ludzkie. W tym zrozumieniu problemu powołania człowieka rzadko wspomagają popularne gry zręcznościowe i fora społecznościowe: miłość i wiara należą do zdecydowanie innego porządku niż hipertekst. Technika przekazu wielkich wartości polega na spotkaniu, na rozmawianiu, przeżywaniu i dzieleniu się.

Statystyczny młody człowiek w środowisku WWW spędza wiele czasu. Za wiele. Dostępne badania z przełomu tysiącleci wykazywały np., że w Kanadzie podczas pierwszych 12 lat edukacji szkolnej 11 tys. godzin uczniowie poświęcali na zajęcia szkolne, 15 tys. godzin przebywały przed telewizorem, a 10,5 tys. godzin zajmowało im słuchanie muzyki pop. Współcześnie mediana medialnej aktywności wyraźnie przesunęła się w kierunku mediów cyfrowych, w których środowisku młoda osoba przebywa nawet kilka godzin dziennie $^{11}$. Polacy przebywają w sieci średnio 1,3 godziny dziennie ${ }^{12}$. To średnie wyliczenie należy interpretować zgodnie z obserwowaną tendencją: to ludzie młodsi, zwłaszcza młodzież i studenci, wyśrubowują statystyki Polaków w przebywaniu w sieci ${ }^{13}$.

Warto w tym kontekście przytoczyć również koncepcję remediacji autorstwa Jaya Davida Boltera. Uczony definiuje remediację jako rozszerzenie i ulepszenie cech jednego medium przez inne, nowsze medium i inną, najczęściej nową technologię. „Tego typu

\footnotetext{
${ }^{10}$ Por. J. Pyżalski, M. Klichowski, M. Przybyła, dz. cyt., s. 15-16.

${ }^{11}$ Por. Młodzież a Internet - raport z badań CBOS, http://www.uzaleznieniabehawioralne.pl/raporty-z-badan/mlodziez-a-internet-raport-z-badan-cbos/ (18.04.2017).

${ }^{12}$ Por. K. Gurba, Sieć i życie w standby, w: Bramy prawdy i wiary, Benedykt XVI o mediach, Kraków 2016, s. 136.

${ }^{13}$ Por. Młodzież a Internet - raport $z$ badań CBOS, dz. cyt.
} 
proces możemy zaobserwować już u starożytnych Greków, którzy to dokonali remediacji literatury ustnej, zapisując ją na zwojach papirusu, angażując tym samym kolejny ludzki narząd - oko, co sprawiło, że słowa nabrały innego znaczenia w rzeczywistości ludzkiej. Kolejnym wielkim przełomem remediacyjnym było wynalezienie druku przez Gutenberga w XV wieku. Trzeba podkreślić, że proces remediacji nie ogranicza się tylko do pisma. Dla przykładu, współcześnie również film ulega remediacji na rzecz gier komputerowych, które to w swej materii coraz częściej korzystają z technologii filmowych, starając się w ten sposób wzbogacić przekaz poprzez wprowadzenie interaktywności. W obecnych czasach jednak to internet stanowi medium, które zmienia niemalże każdą $\mathrm{z}$ form wizualnego i tekstualnego przekazu, co dotyczy również druku"14.

Proces remediacji oddziałuje w ten sposób na środowisko rozkrzewiania wiary. Potrzeba więc pewnej adaptacji naszego przepowiadania. Remediacja dotykała przekazu prawd życia duchowego zaobserwowanego już przez autora Listu do Rzymian. Wiara, będąc darem łaski, rodzi się w określonym tu i teraz, z tego, czego się słucha, co się czyta, na co się patrzy. Ale dziś wiara u wielu „obumiera” albo jest zagłuszana podczas bezrefleksyjnego słuchania, oglądania i czytania. Dotykamy tutaj sedna problemu.

Podsumowując ten etap rozważania, należy dodać zachętę do wysiłku ewangelizatorów. W istniejącym prawodawstwie państw demokratycznych ograniczenia w kreacji czy funkcjonowaniu świata mediów dotyczą ogólnego bezpieczeństwa instytucji państwa i przestępstw przeciwko prawu stanowionemu. W praktyce życia przesuwa się akcentowanie i przenosi się odpowiedzialność za wpływ mediów z ich twórców na odbiorców ${ }^{15}$. Wychowanie do umiejętnego korzystania z mediów w kontekście edukacji i przekazu prawd wiary to właściwie zadanie na wczoraj. Już od lat 60 . zeszłego wieku zajmuje się tym problemem UNESCO, agenda Organizacji Narodów Zjednoczonych, a encyklika Piusa XII Miranda prorsus (8 września 1957) zaleca „wielki wysiłek wychowawczy, celem przygotowania widza, słuchacza czy czytelnika nie tylko do zrozumienia języka właściwego każdemu z mediów, ale i do pogłębionej oceny przekazu” (n. 57). Taka edukacja medialna powinna być realizowana przede wszystkim w instytucjach do tego powołanych, tzn. w szkołach i uniwersytetach. $\mathrm{W}$ tym procesie dydaktycznym porządkowania wiedzy o mediach i zdobywania umiejętności korzystania z mediów bierze udział nauczyciel wiary, rodzic, wychowawca, duchowny.

Należy również pamiętać o wielkim przesłaniu Karola Wojtyły - Jana Pawła II, który sam posługiwał się w ewangelizacji, formacji i diakonii najnowszymi metodami komunikacji. Wysyłał np. adhortację pocztą elektroniczną do Oceanii. Jego pojęcie "nowa ewangelizacja” ma swoją konotację powiązaną z przemianami mentalności nowych pokoleń. Nowa ewangelizacja jest częścią procesu ewangelizacyjnego i propozycją dla zeświecczonego społeczeństwa, które wyrosło z głębokiej wiary przodków, ale teraz niejako wyzbyło się praktykowania wiary. Nowa ewangelizacja nie jest dlatego ani klasyczną misją ad gentes ani apostolstwem. Polega na głoszeniu słowa Bożego tym, którzy są ochrzczeni, ale porzucili swoją wiarę czy zaniechali praktyk religijnych.

\footnotetext{
14 M. Wądołowski, Literatura hipertekstowa..., dz. cyt.

15 Por. W. Strykowski, Media i edukacja medialna w tworzeniu współczesnego społeczeństwa, www.kmti. uz.zgora.pl/pages/referaty/strykowski.pdf (12.05.2004).
} 
Do nich ma trafić cała głębia przekazu Ewangelii i nauka o zmartwychwstaniu. Wezwanie papieża do nowej ewangelizacji zabrzmiało już w 1979 roku jak proroctwo. Stało się to w pobożnej części Europy, w krakowskiej Nowej Hucie w wielotysięcznym tłumie, który pamiętał obronę krzyża przed komunistami. Papież przewidywał już odpływ wiary $\mathrm{w}$ następnych pokoleniach, zgodnie $\mathrm{z}$ tendencjami obserwowanymi $\mathrm{w}$ świecie zachodnim. Współczesna misja wspólnoty wierzących w Chrystusa powinna dotykać nowego środowiska życia i musi uwzględnić zmiany cywilizacyjne i kulturowe, dokonujące się również w sposobach komunikowania. Stąd konieczność media-edukacji staje się priorytetem nauczyciela wiary.

\section{Pola edukacji medialnej}

W edukacji medialnej postuluje się przede wszystkim przygotowanie do krytycznego odbioru mass mediów. Społeczności, film, wiadomości online, rtv, gra komputerowa czy newsy poczytnego tabloida winny być oceniane nie tylko ze względu na używaną w nich specyficzną i jakże często atrakcyjną poetykę, lecz również, a może przede wszystkim, ze względu na przekazywane treści. Krytyczne spojrzenie na kontent jest niezbędne wobec medialnego „przesycenia” życia.

Przechodząc do edukacji medialnej, czyli meritum postawionego zagadnienia, wydaje się, że należy przyjąć za jej ogólne cele ${ }^{16}$ :

- przygotowanie do posługiwania się mediami jako narzędziami pracy intelektualnej (rozwój indywidualny) i pracy zawodowej. W przypadku katechetów czy nauczycieli będzie to m.in. przygotowanie do powszechnego stosowania mediów w szkole, tzw. kształcenie multimedialne. Również w przypadku rodziców posługiwanie się nowoczesnymi mediami czy sposobami komunikacji pozwoli m.in. na lepszy kontakt z dziećmi i młodzieżą,

- wykształcenie postawy krytycznego odbioru mediów jako narzędzi przekazu informacji oraz kształtowania systemu wartości i postaw. Chodzi tu o kompetencje odbiorców do odszyfrowania przekazu medialnego oraz o zachowanie autonomii ucznia w wartościowaniu tego przekazu,

- właściwe korzystanie z mediów jako narzędzi zabawy i rozrywki. Cel ten określić możemy jako antropologiczny, zwraca się tu uwagę np. na czas poświęcony bezpośrednim kontaktom z ludźmi w codziennym życiu, porównując z czasem przeznaczonym na obcowanie z mediami.

W czasie zajęć szkolnych - również w czasie katechezy - należałoby być świadomym programu edukacji medialnej. Jeden z pierwszych i całościowych programów został wdrożony jako dyscyplina obowiązująca w kanadyjskich szkołach państwowych już w roku 1987. Wydaje się, że właśnie programy klas 7 i 8 kanadyjskiej szkoły objęły

${ }^{16}$ W. Strykowski, Media i edukacja medialna, dz. cyt., s. 4. 
interesujące zagadnienie w sposób wyczerpujący, porządkując materię wokół sześciu obszarów tematycznych ${ }^{17}$ :

- instytucje medialne - kto komunikuje, za czyje pieniądze i dlaczego? - w tym bloku omawiane są instytucje regulujące media, dystrybutorzy i podmioty produkujące przekaz medialny: prasa, radio, telewizja, wytwórnie filmowe, agencje reklamowe, drukarnie, portale internetowe, społeczności itd. oraz ich intencje, wyniki i cele ekonomiczne,

- kategorie, typologie, gatunki mediów - jakie istnieją typy i rodzaje mediów? rozróżnia się wówczas media drukowane od elektronicznych, telewizję od kina, fonografię od radia, plakat od fotografii artystycznej, dokument od fabuły, news od publicystyki, teatr od koncertu rockowego, vlog od bloga itp.

- technologie mediów (tworzenie mediów) - daje się odpowiedź na pytanie, jak komunikaty medialne są wykonywane i projektowane? Chodzi tu również o praktyczne zastosowanie zdobyczy technicznych dostępnych uczniom i umożliwienie im tworzenia wystaw fotograficznych, nagrań fonicznych i filmów wideo, stron internetowych i technologii online,

- język mediów - w jaki sposób wiadomo, co znaczy komunikat przekazany przez media? Refleksja w tej części programu dotyczy wyjaśnienia kodów czy języków, jakimi operują media: struktury narracyjne, figury retoryczne, funkcje i sposoby przemawiania oraz ich znaczenie dla publiczności, osoby dramatu, dramaturgia,

- odbiorcy mediów - to zagadnienie dotyczy pytania o tego, kto odbiera media i z jakim skutkiem ten odbiór się dokonuje. Chodzi o tzw. targetowanie, a więc zainteresowanie nadawcy adresatem przekazu medialnego. Jakie są typy odbiorców, w jaki sposób można osiągnąć zainteresowanie wybranej części audytorium. Przedmiotem rozważania podczas zajęć są zachowania publiczności: jak odbiorcy wybierają, konsumują i reagują na poszczególne treści medialne.

- media i idee - jakie treści przedstawiają współczesne media? Wyjaśnia się tutaj i poszukuje relacji między komunikatem medialnym i rzeczywistością, szuka się idei, znaczenia, wartości, postaw, jakie „konstruuje” konkretna treść komunikatu w związku z aktualnymi wydarzeniami, ludźmi, miejscami. Obserwuje się osoby publiczne i sposoby ich prezentowania ze strony mediów, wskazuje się na kreowanie stereotypu i jego konsekwencje w opinii publicznej.

Wyżej wymienione cele oraz bloki programowe nie kończą naszego zaangażowania w poznanie świata mediów w kontekście komunikacji wiary. Poznajmy również charakterystykę deterministycznej teorii mediów.

\section{MEdIA SĄ JEZZYKIEM}

Kilka rozróżnień ważnych dla edukacji medialnej dostarcza też teoria. Determinizm technologiczny głoszony m.in. przez McLuhana opisuje rolę mediów jako środowiska

${ }^{17}$ Por. L. Masterman, A scuola dei media, Brescia 1994, s. 114n. 
poszerzającego centralny układ nerwowy człowieka. Niektóre tezy winny stać się bazą procesu edukacji do świadomego używania mediów. Uczciwie należy przyznać, że te przekonania nie wynikają z uprzedzenia do mediów, ale ich wnikliwej obserwacji ${ }^{18}$ :

- wszystkie media są „konstrukcją”. Media nie są odbiciem rzeczywistości zewnętrznej, lecz reprezentacją ułomnych decyzji ludzkich i technicznych ograniczeń. Pierwszym zadaniem jest więc nauczyć odkrywać i rekonstruować to, co zostało wyprodukowane według pewnego punktu widzenia i konkretnego zamiaru,

- media konstruują rzeczywistość. Każdy z nas buduje swój światopogląd w oparciu o doświadczenie nabyte w życiu, otrzymane informacje i osobistą intuicję. Problem w tym, że dziś wiele obserwacji empirycznych pochodzi nie z bezpośrednich obserwacji, lecz z „zapośredniczeń” medialnych: np. przekonanie dzieci $\mathrm{z}$ wielkich miast o tym, że krowa jest fioletowa jak w reklamie pewnej czekolady. Odpowiada to zupełnie sytuacji: wśród dorosłych panuje przekonanie, że to, co powiedziano w telewizji, jest całą prawdą w danej kwestii,

- odbiorca negocjuje znaczenie mediów. Młody człowiek powinien zrozumieć swoja rolę w grze z mediami: ma na drodze przyjmowania komunikatów samodzielnie nadać sens i znaczenie otrzymanej informacji. W tym procesie recepcji ważne są oczywiście:

- wiedza, potrzeby i zainteresowanie osobiste, jak również kompleksy i słabości,

- podłoże rodzinne i kulturowe,

- postawy i przesądy (np. uprzedzenia),

- kontekst życiowy, w którym się człowiek znajduje (radość, przygnębienie),

- działania mediów mają implikacje reklamowe. Te działania są częścią największego z biznesów współczesnego świata: obrotu towarami. Mówiąc brutalnie: media zdobywają publiczność, aby dostarczyć ją reklamodawcom,

- media rozpowszechniają ideologie i opowiadają się za konkretną hierarchią wartości. Wszystkie działania mediów, każdego na swój sposób, są promocją pewnego stylu życia, często bazującego na konsumeryzmie, egzaltacji sukcesu itd.,

- media mają oczywiste lub ukryte implikacje społeczne i polityczne. Media w historii zmieniły głęboko styl życia większości rodzin. Media mogą zniszczyć czy zbudować autorytet prawie każdej postaci życia politycznego,

- forma i treść są ściśle powiązane w przekazie medialnym. Każde z mediów ma swoistą gramatykę i kodyfikuje rzeczywistość w swój specyficzny sposób; to samo wydarzenie zostaje zaprezentowane w inny sposób ze względu na medialną różnicę formy przekazu,

- każde z mediów ma swoją specyficzną formę estetyczną. Młodzi winni w praktyce nie tylko dekodyfikować i interpretować przekaz danego medium, ale również umieć delektować się pełnymi formami estetycznymi dostarczanymi przez poszczególne rodzaje mediów: muzyka, kino, teatr, książka itd.

18 L. Masterman, A scuola dei media, dz. cyt., s. 115-116. 
Wyżej wymienione idee dają pewien ogólny obraz edukacji do odbioru mediów, w którą powinien się włączyć dojrzały odbiorca. Należy tutaj dodać, że edukacja medialna ma również charakter kształcenia nieformalnego i ustawicznego, zwłaszcza jednak u tego, który odpowiedzialnie pragnie komunikować Dobrą Nowinę jako nauczyciel wiary.

Parafrazując sformułowaną przez McLuhana tezę, możemy wskazać, że każde medium jest swoistym „językiem”, określoną ramą przedstawionych spraw. Określone medium wyzwala bowiem przyswojenie pewnej gramatyki języka, sposobu narracji, ale i ograniczenia przekazu do tego sposobu budowania komunikatów. Przechodząc do bardziej szczegółowych rozważań, w tym miejscu warto wspomnieć również specyfikę „języków”, czy lepiej mówiąc: poetyk, gramatyk, jakich używamy w mediach. Zacznijmy od prasy, potem pokrótce scharakteryzujemy i omówimy to, co bardzo istotne dla świata dorastających ludzi, rozrywkowy i „lekki” świat muzyki i radia, zidentyfikujemy też dramaturgiczny język audiowizualny oraz wskażemy niektóre aspekty istotne dla "gramatyki” gier komputerowych. Na koniec powrócimy do bogactwa języka internetu jako źródła codziennej wymiany komunikatów.

\section{Prasa}

Prasa to swego rodzaju ojczyzna dziennikarstwa. Nie wchodząc w precyzyjne rozróżnienia rodzajów dziennikarskich, trzeba dla naszego użytku wyróżnić dwa główne nurty pisania czy kreowania komunikatów. Mówiąc w uproszczeniu, dziennikarstwo informacyjne (news, notatka, grafika, dokumentacja, korespondencja, nota biograficzna) ukazuje czytelnikowi odpowiedź na pytania podstawowe: co się stało? kiedy się stało? gdzie się stało? jak się stało? a dziennikarstwo opinii (reportaż, analiza, opinia, kolumna, krytyka, list do redakcji, winieta, wywiad, sylwetka) daje odpowiedź przede wszystkim na pytanie: dlaczego coś się stało? jaki będzie dalszy rozwój wypadków? Pierwszy typ dziennikarstwa naznaczony jest większą dozą faktografii, stanowi o tym, że jesteśmy poinformowani, ten drugi najczęściej wyraża opinie osobiste autorów, a subiektywizm ocen jest wręcz cechą pożądaną. To rozróżnienie jest fundamentalne dla każdego tekstu pisanego. Pytamy w mediach informacyjnych o to, czy jesteśmy już wystarczająco poinformowani. Od tekstów publicystycznych żądamy raczej przenikliwości i dywagacji.

Należy też wiedzieć, że tworzeniu tekstów dziennikarskich towarzyszy reguła sformułowana niegdyś przez wielkiego Walerego Pisarka: „żeby ktoś nas zauważył, żeby ktoś nas przeczytał lub wysłuchał, żeby ktoś nas zrozumiał, żeby ktoś nam przyznał rację, żeby ktoś nas zapamiętał" ${ }^{19}$.

Tytuł artykułu i zdjęcia, fotografie towarzyszące tekstowi pisanemu powstają w redakcjach zazwyczaj odrębnie. Tytuły mają zachęcić do czytania, do prześledzenia nawet tylko kilku wersów tekstu. W wielu redakcjach tytuł jest wytworem wspólnym

19 W. Pisarek, Nowa retoryka dziennikarska, Kraków 2011, s. 22. 
redaktorów lub specjalistów/językoznawców, którzy poszukają nowych treści i niuansów języka. Tytuł jest często sam w sobie dziełem. Zdjęcia zazwyczaj ukazują dynamikę postaci czy sytuacji omawianej w artykule i są ekspresją uczuciowości. Tytuł, podtytuł i fotografia służą razem wyrażeniu jakiegoś napięcia, które można odkryć dopiero w samym tekście.

Lead (ang.), czyli pierwszy akapit, zazwyczaj dwa lub trzy pierwsze zdania tekstu prasowego, określa największą „zdobycz” informacyjną poniżej następującej treści. Leady pokazują „serce” omawianej historii i mają przekierowywać czytelnika wprost do opowiadania. Po nich następuje właściwy tekst artykułu pokazujący stan rzeczy w porządku odwróconej piramidy. Najbardziej szczegółowy czy backgroundowy opis zaistniałej sytuacji znajdziemy zazwyczaj na końcu tekstu pisanego.

W czasie nauki korzystania z prasy użyteczną rolę pełnią tzw. „prasówki”. W czasie wspólnej lektury dzienników czy tygodników można zwrócić uwagę na podstawowe elementy: tytuł, zdjęcie, lead oraz tekst właściwy. Występujące osoby, główny problem, słowa klucze, wyróżnienie elementów wartościujących, układ argumentacji w danym artykule, czytelna w użytych sformułowaniach sympatia/antypatia i końcowe przesłanie autora stanowić mogą niejako ramy tabeli analitycznej do badań nad tekstem dziennikarskim. Pozostaje jeszcze zastanowić się nad wiarygodnością źródeł tekstu oraz wpływem tabloidyzacji na formułowany przekaz. Interpretacje i finalne wnioski należy pozostawić do przemyślenia samemu odbiorcy.

\section{RADIO}

Język radia to mniej lub bardziej subtelne złożenie muzyki i słowa mówionego, które w różnych proporcjach i charakterystykach stanowią o profilu programu danej radiostacji. Ten język radiowy wyróżnia kultura szybkiej obsługi, cykl życia newsa radiowego, czyli starzenie się informacji, rzadko przekracza 60 minut. To, co było aktualne godzinę temu, teraz jest już przestarzałe. Ważnym pojęciem w poznaniu funkcjonowania medium radiowego jest format, co oznacza konstrukcję takiej oferty programowej w radiu, która spowoduje ściągnięcie jak największej liczby słuchaczy spełniających kryterium, jakim jest wybrana grupa docelowa dla której radio się tworzy ${ }^{20}$. Format radia jest swoistą mieszaniną muzyki i tematów poruszanych na antenie, które niejako „dobierają” określonego słuchacza. Radio sformatowane to radio, które dobrze zaspokaja potrzeby wybranego słuchacza. Kampania o pozyskanie słuchacza i najczęściej nim zainteresowanego reklamodawcy odbywa się według schematu:

- analiza, segmentacja rynku, na którym działa lub ma działać stacja radiowa;

- wybór grupy docelowej, czyli precyzyjne określenie grupy, dla której należy formatować daną stację;

${ }^{20}$ Por. A. Garcarek, Realizacje muzycznych formatów stacji radiowych na polskim rynku medialnym, „Folia Litteraria Polonica” 17 (2012) nr 3, s. 182-188. 
- pozycjonowanie, czyli stworzenie muzycznego formatu radia i określenie jego cech na antenie, tak by najlepiej odzwierciedlały potrzeby grupy docelowej, oraz zaplanowanie odpowiedniej akcji promocyjnej.

Posłużmy się przykładami: ciągle popularny format GOLD AC - „złotoprzebojowy”, charakteryzuje granie największych hitów sprzed lat (w Polsce Radio Złote Przeboje konfederacja 18 stacji). Obecnie zalicza się tutaj muzykę lat 60., 70., 80. i 90. Jednak to format AC (Adult Contemporary) charakteryzuje większa otwartość na słuchacza oraz granie dla miłośników różnych rodzajów muzyki. Format ten adresowany jest głównie do osób w wieku 25-54 lata. Stacja AC (w Polsce Jedynka, RMF FM, ZET) prezentuje głównie gatunki muzyczne pop, rock oraz lekki dance (głównie w godzinach wieczornych), zarówno sprzed lat, jak i współczesny. Ważne też jest wyróżnienie formatu NEWS/TALK (Tok FM), którego reprezentacji nie brakuje również w Polsce. Stacje takie powinny oferować rzetelne informacje i programy publicystyczne. Wiadomości przedstawiane są częściej, pozostały czas wypełniają głównie dyskusje publicystyczne i reportaże. Muzyka schodzi tutaj na dalszy plan ${ }^{21}$.

Edukacyjna formacja winna uzdalniać w kierunku wszechstronnego poznania muzycznego spektrum radiofonii, np. gatunków muzyki i publicystyki, a tym samym unikać jednowymiarowego spojrzenia na antenową rzeczywistość. Słuchacze powinni zdać sobie sprawę z różnorodności radiowej oferty programowej, tak lokalnej, jak i ogólnopolskiej. Warto też pochwalić się lokalnymi stacjami, które w znakomitej większości ośrodków i diecezji funkcjonują z powodzeniem.

\section{Audio-WIDEO}

Teatr nauczył człowieka języka dramaturgii. Film, telewizja i reklama audiowizualna korzystają z tego narzędzia. Język filmowy i telewizyjny można scharakteryzować jednym wyrażeniem: udramatyzowane kreowanie napięcia. Od czasów dramatu greckiego i Poetyki Arystotelesa każda scena widowiska teatralnego czy filmu rządzi się wewnętrzną dramaturgią; informacja o bohaterze nie jest tylko związana z pewną historią opowiadaną od początku do końca, ale z wewnętrznym konfliktem, intrygą. Główny bohater jest bliski lub daleki rozwiązania swojego głównego problemu, każda scena musi budować i służyć całości scenariusza. Ważnym elementem jest prawdopodobieństwo historii opowiadanej przez reżysera. Cały film, sztuka teatralna, relacja telewizyjna czy nawet poszczególne ujęcia i sekwencje obrazu mają wywołać u widza przekonanie o nieuchronności i prawdziwości tego, co następuje. Widzowie czy telewidzowie są bezustannie „uwodzeni” atrakcyjnością historii i smakują identyfikacji z „osobą” dramatu. Ważna jest nie tyle kompletność historii, ile dramatyzacja opowiadania. Obraz i dźwięk mają za zadanie przedstawić tylko wierzchołek góry lodowej, zostawiając widzowi wielki margines na wyobrażenia. Opowiadana historia powinna kończyć się klasycznym

21 A. Garcarek, Realizacje muzycznych formatów stacji radiowych..., dz. cyt., s. 184-187. 
katharsis publiczności lub jego nowoczesnymi odmianami. Fabuły dramatyczne produkcji najczęściej zbudowane są według zasad sztuki antycznej:

- I etap - następuje przedstawienie postaci i głównego problemu;

- II etap - perypetie bohatera i kulminacja dramatu, problem główny staje się nierozwiązalny, bohater znajduje się w sytuacji beznadziejnej lub granicznej;

- III etap - nieoczekiwana zmiana biegu zdarzeń, rozwiązanie dramatu, wyjście bohatera z opresji, optymistyczne, komediowe lub tragiczne zakończenie.

Te same zasady dramatyzacji obowiązują często w montażu krótkich, 90-sekundowych relacji wykorzystywanych w telewizyjnych dziennikach, reklamówkach i dłuższych teledyskach, filmach dokumentalnych czy fabularnych TV. Jest w nich sztuką opowiedzenie całej historii w sekwencjach obrazów lub scen. Naszych słuchaczy, uczniów, studentów, audytorium uniwersytetów trzeciego wieku należałoby więc nauczyć analizy treści audiowizualnych, zapraszając do rozmowy profesjonalistę: aktora, reżysera, scenarzystę. Należy nauczyć słuchaczy selekcji najważniejszego problemu postawionego w obrazie, krytycznego potraktowania postaw bohatera (-ów), znalezienia w scenie teatralnej, filmie czy innej prezentacji audiowizualnej klimaxu (punktu kulminacyjnego), a nawet kreacji filmu wideo czy sceny teatralnej. Takie żywe wejście na scenę pozostawi w każdym słuchaczu trwałe rozróżnienie miedzy fabularną fikcją i życiem, tym bardziej że statystyczny Polak bywa w teatrze bardzo rzadko.

Osobnym wątkiem jest reklama audiowizualna, gdzie do wspomnianej dramaturgicznej emocjonalności dochodzi specjalnie zbudowany ładunek perswazyjności. Jeśli przyjąć założenie Perelmana o tym, że każda wypowiedź jest retoryczna i niesie określony ładunek perswazji, to język reklamy trzeba uznać za bombę perswazyjną. Reklamie (czy kryptoreklamie) ulegamy bezpośrednio lub pośrednio wszyscy, bez wyjątku. Mechanizmy wspólnoty świata i języka, symplifikacji hierarchii wartości i bezalternatywnego odbioru, czyli stereotyp o wspólnocie świata nadawcy i odbiorcy, odrealniony czarno-biały świat wartości i zwolnienie z decyzji interpretacyjnych stanowią o olbrzymiej sile perswazji reklamy. Jako odbiorcy komunikatów promocyjnych wciągani jesteśmy często w grę, której zasady nie są nam bliżej znane. Najbardziej bezbronne i nieuodpornione są dzieci. Na katechezie i w pracy z rodzicami katechizowanych potrzebne jest ukazanie na konkretnych przykładach tych mechanizmów rządzących perswazją reklamową.

\section{GRY WIDEO}

Warto przy rozważaniu języka wspomnieć trzy kwestie związane z grami wideo, czyli komputerowymi ${ }^{22}$. Pierwsza konstatacja: gry komputerowe stanowią dziś olbrzymią gałąź biznesu i konkurują z produkcjami Hollywoodu. Produkcja gier jest wielce kosztowna, ale producenci wyprzedzają się w nowych propozycjach, edycjach $\mathrm{i}$ animacjach.

${ }^{22}$ Obydwa określenia interaktywnej rozrywki, „gra wideo” i „gra komputerowa”, są stosowane zamiennie w terminologii naukowej. Por. A. Pitrus, Olbrzym wychodzi z cienia: gry wideo jako awangarda współczesnej kultury audiowizualnej. W: Olbrzym w cieniu. Gry wideo w kulturze audiowizualnej, Kraków 2012, s. VII. 
Informacja druga: olbrzymia popularność gier komputerowych wynika z multimedialnego i interaktywnego języka używanego do komunikowania z odbiorcą. Nagromadzenie wielu osiągnięć technicznych i wykorzystanie tychże w grach komputerowych czyni z nich najdoskonalszą zabawkę zarówno dla dzieci, jak i nierzadko dla dorosłych, pozwalając na przeżywanie interaktywnych przygód. Niestety ten bogaty język, czyli „polifoniczność" dźwięku, atrakcyjnej grafiki, animacji, dramatyzacji scen i sensacyjności fabuły bywa najczęściej wykorzystywana w grach o tematyce budzącej uzasadnione obawy. Popularne gry wideo przerażają ogromnym ładunkiem okrucieństwa i agresji. "Zadaniem gracza jest często niszczenie, zabijanie lub okaleczanie ciała przeciwnika różnymi dostępnymi środkami (np. nożem, piłą tarczową itp.). Szczególnie popularne wśród graczy są strzelaniny pt. Doom, Quake, Blood, gdzie gracz niejako wciela się w bohatera i ogląda świat jego oczami. Przed sobą widzi ręce tego bohatera oraz wybraną przez siebie broń. Dokładnie widoczni są atakujący przeciwnicy, akt zabijania oraz ich zakrwawione szczątki. Wśród bijatyk najpopularniejsze są te najbardziej krwawe, m.in. Mortal Kombat («Śmiertelny pojedynek»), Street Fighter («Uliczny wojownik»), Total Carnage («Totalna rzeź»)»"23.

Taki multimedialny język agresji bywa atrakcyjny z powodu wywoływanych emocji oraz zwiększonej sprzedaży, lecz niszczy psychikę, wytwarza iluzoryczny świat bezkarności i łudzi możliwością wykorzystania kilku żyć, towarzysza zabaw zastępuje komputerem lub konsolą, a na dłuższą metę może powodować utratę kontaktu z człowiekiem spędzającym całe godziny przy konsoli.

Trzecia informacja: gry ze względu na wspomnianą atrakcyjność nie powodują uczucia nudy, dostarczają niezapomnianych przeżyć. Na tym tle możliwe jest silne uzależnienie. Dlatego przede wszystkim nauczyciele, rodzice, ale i wychowawcy dzieci powinni rozpoznawać symptomy uzależnienia od gier i mieć wiedzę dotyczącą rozsądnego i bezpiecznego z nich korzystania oraz winni te zasady rozpowszechniać. Zasady te dotyczą między innymi ${ }^{24}$ :

- dokładnej znajomości gier używanych przez dzieci i młodzież,

- ustalenia zasad korzystania $\mathrm{z}$ gier, częstszego proponowania dzieciom przede wszystkim gier edukacyjnych, logicznych, encyklopedycznych czy interaktywnych kursów języków obcych,

- obecności rodziców w domu podczas korzystania przez dziecko z gry,

- ograniczenia czasu spędzanego przy komputerze w związku z wiekiem,

- reguły: najpierw obowiązki, potem gra,

- częstego organizowania spotkań rówieśniczych z innymi, aktywizującymi formami spędzania wolnego czasu,

- świadomości, że dzieci nie potrzebują elektronicznych zabawek, aby być szczęśliwe.

W tym miejscu należy wspomnieć, że multimedialność religijna również istnieje i należałoby domową biblioteczkę gier wzbogacić w ten rodzaj pomocy edukacyjnej.

${ }^{23}$ Por. I. Ulfik-Jaworska, Czy gry komputerowe moga być niebezpieczne?, http://www.katolik.pl/czy-gry-komputerowe-moga-byc-niebezpieczne-,2110,416,cz.html?s=5 (20.10.2017).

${ }^{24}$ Por. I. Ulfik-Jaworska, Czy gry komputerowe mogą być niebezpieczne?, dz. cyt. 
Dla najmłodszych choćby godna polecenia jest gra w języku polskim „Być uczniem Jezusa”. Gra wideo zaprasza w miejsca, w których żył i nauczał Jezus Chrystus. Można w niej spotkać gorliwych wyznawców Jezusa, jak i tych, którzy szkodzą rodzącym się wspólnotom chrześcijan. Ciekawostkom dodaje kolorytu np. św. Maria Magdalena, opowiadając o Jezusie (głosu użyczyła jej polska aktorka Alina Janowska ${ }^{25}$ ). Jest też inna religijna alternatywa dla gier, którą można zaproponować ${ }^{26}$.

Innym zjawiskiem godnym zaprezentowania ze względu nawet na naruszanie bezpieczeństwa społecznego są niektóre gry interaktywne. W Polsce opinię publiczną poruszył mocno przypadek tzw. gry „niebieskiego wieloryba”. Przypadki samookaleczeń dzieci i młodzieży wynikały bezpośrednio z używania sieci bez kontroli i odpowiedniej wiedzy. Szkoły otrzymały list, w którym Ministerstwo Edukacji Narodowej (MEN) prosi o uwrażliwienie rodziców na kwestię związaną z bezpieczeństwem $\mathrm{w}$ sieci oraz korzystaniem z gier komputerowych i wideo stanowiących potencjalne zagrożenie dla młodych. MEN apelowała do rodziców, żeby zwracali baczną uwagę na to, jakie interaktywne zabawy uprawiają czy jakie kontakty zawierają najmłodsi użytkownicy sieci. MEN podaje nawet numery telefonów, pod którymi opiekunowie prawni małoletnich mogą otrzymać pomoc. Skala zjawiska może nie napawa niepokojem, ale problem stał się dotkliwy: brak reguł w używaniu sieci. Doprowadziło to wielu młodych do wykonania szeregu niebezpiecznych i groźnych poleceń anonimowego moderatora, a w konsekwencji do wskazania na samobójstwo jako rozwiązanie finalne "gry" ${ }^{27}$. Można wnioskować, że kwestia cyberbezpieczeństwa stanowi w tej chwili pierwsze założenie w procesie wychowania. Tak więc problem przekazu wiary w mediach zawsze zacząć należy od nauki odpowiedzialnego ich użytkowania.

\section{INTERNET}

Globalna sieć komputerowa oparta na protokole TCP/IP pozwala na korzystanie ze stale rosnącego zasobu informacji, znosi tradycyjny podział na nadawców i odbiorców w procesie komunikowania: każdy jednocześnie może być i nadawcą i odbiorcą. Internet posługuje się swoistą gramatyką interaktywności. Uczestnik może anonimowo przeglądnąć internetowe wydania czasopism, skomentować teksty, wziąć w udział w błyskawicznym sondażu, czatować do woli z kilkoma nowo poznanymi internautami,

${ }_{25}$ Por. https://e-religijne.pl/pl/c/Religijne-gry-komputerowe/324 (25.10.2017).

${ }^{26}$ Por. https://wydawnictwowam.pl/plyty/dla-dzieci (21.11.2017).

${ }^{27}$ Troje nastoletnich dzieci z powiatu pyrzyckiego (województwo zachodniopomorskie) dokonało samookaleczenia na ramionach i przedramionach poprzez wycięcie ostrym narzędziem symbolu f50. Prokuratura Okręgowa w Szczecinie prowadzi już śledztwo dotyczące namawiania tych trojga ustalonych dotychczas małoletnich do targnięcia się na własne życie. Bliżej nieustalona osoba, tzw. „opiekun”, wydaje uczestnikom "gry” różnego rodzaju polecenia i zleca zadania do wykonania, np. dokonanie samookaleczeń, oglądanie „strasznych” filmów, chodzenie po torach kolejowych. Ostatnim zadaniem w tej grze jest skok z dachu wysokiego budynku. Do namowy do tych czynów dochodzi za pośrednictwem internetu, podczas interaktywnej "gry” o nazwie „niebieski wieloryb”. Zob. https://pk.gov.pl/aktualnosci-prokuratury-krajowej/niebezpieczna-dla-dzieci-gra-o-nazwie-niebieski-wieloryb-dotarla-do-polski.html\#.WNZcqRiBg_U (25.03.2017). 
sprzedawać i kupować, stwarzać listy dyskusyjne, mailować, podzielić się poglądami na forach tematycznych, rozmawiać i oglądać swoich rozmówców, komentować, lajkować, hejtować itd.

Internet tworzy cyberprzestrzeń i jako środek przekazu skutecznie konkuruje z prasą, radiem i telewizją. Można, korzystając z powyższych rozważań, określić to medium jako wielkiego remediatora. Co ciekawe, internet uznawany jest również za najbardziej demokratyczne medium ze względu na częsty brak odredakcyjnej cenzury przekazywanych informacji. To niesie określone niebezpieczeństwo rozpowszechniania treści uznawanych za rasistowskie, pornograficzne itp. Wiele portali czy społeczności internetowych rezerwuje sobie jednak prawo recenzji, blokowania i oceniania kontentu.

Większość wielkich pomysłów organizujących submedia internetu wzięła swój początek w USA. Zwróćmy uwagę choćby na niektóre ${ }^{28}$ :

- Facebook to portal, którego chyba nikomu nie trzeba przedstawiać. Powstał w 2004 roku, pierwotnie tylko w obrębie społeczności Uniwersytetu Harvarda. Gromadzi gigantyczne ilości danych i korzysta z niego około 1,4 miliarda użytkowników z całego świata. W Polsce jest to serwis społecznościowy numer jeden. Jego użytkownicy mogą udostępniać treści i zdjęcia oraz reagować na pojawiające się ogłoszenia innych, tworzyć grupy i wydarzenia, a także organizować działania reklamowe w obrębie strony;

- bardzo reprezentatywny stał się również Twitter, serwis społecznościowy umożliwiający mikroblogowanie. Jego cechą rozpoznawczą jest limit wpisu w postaci tylko 140 znaków oraz korzystanie z hashtagów, które pozwalają na agregację treści do odpowiednich znaczników. Ta metoda znacznie ułatwia wyszukiwanie interesujących tweetów;

- Instagram to również jeden z najpopularniejszych serwisów społecznościowych, który ułatwia publikowanie zdjęć, a nawet krótkich filmików. Obecnie ten serwis jest wiodącą platformą dla influencerów i instrumentem reklamowym dla wielu znaczących marek - idealnie wpisuje się w panująca modę na to, co klasyczne, retro i vintage. Początkowo z tej platformy mogli korzystać tylko użytkownicy urządzeń z systemem iOS, ale później umożliwiono aktywność użytkownikom Androida i Windowsa. W 2012 roku serwis został zakupiony przez Facebooka za miliard dolarów. Koszt przejęcia uzmysławia nam skalę przemian medialnych 2.0 ;

- Google+ zadebiutował w 2011 roku i jest siecią społecznościową, która w Polsce jest nieco mniej popularna. W ramach serwisu możemy dzielić się informacjami, tworzyć kręgi znajomych, zintegrować profil z albumem zdjęć czy organizować wideokonferencje;

- nie można na koniec nie wspomnieć serwisu YouTube. To serwis niezwykłej popularności, który powstał w 2005 roku. Koncepcja platformy służy do udostępniania i oglądania materiałów wideo przez identyfikowalnych przez usługę (IP) użytkowników, umożliwia subskrybowanie kanałów oraz komentowanie i ich

${ }^{28}$ Por. https://socialpress.pl/2017/05/22-serwisy-spolecznosciowe-z-ktorych-korzystamy-najczesciej/ (24.11.2017). 
ocenianie treści. W serwisie znajdziemy tysiące twórców, którzy dzielą się vlogami o różnej tematyce. Jest to poza tym, po Google, największa wyszukiwarka.

Nie do przecenienia jest dla nas nauka korzystania z godnych polecenia dla pogłębienia wiary stron, kont, miejsc, społeczności sieciowych. Takie działanie stanowi niezastąpione wsparcie w projekcie utrzymania siebie $\mathrm{w}$ stanie doinformowania o życiu wspólnoty wiary. Możemy korzystać z codziennych komentarzy naszych autorytetów, wierzących vlogerów, możemy również komentować i uczestniczyć w wymianie opinii, dzieleniu się spostrzeżeniami. Adresów takich jak stacja7.pl, mateusz.pl, aleteia.pl czy deon.pl jest w polskojęzycznej sieci już naprawdę sporo.

Nie należy zapominać również o działaniu defensywnym. Powinniśmy po prostu ciągle siebie i innych przynaglać do bezpiecznego korzystania z sieci, czyli ${ }^{29}$ :

- niepodawania obcym swojego adresu mailowego, numeru telefonu, wieku itd., a jeśli takie informacje są wymagane - konsultacji, czy można je podać w konkretnej sytuacji,

- nieufności co do przygodnych znajomości internetowych, nieumawiania się na spotkania w realu,

- unikania stron z niewłaściwymi treściami,

- pamiętania o przestrzeganiu praw autorskich,

- przestrzegania etykiety internetowej i jej 3 głównych zasad: myśl, nie działaj na czyjąś szkodę, nie nadużywaj,

- prawdy o tym, że anonimowość w internecie jest pozorna.

Działania na rzecz bezpieczeństwa w sieci należy wprowadzać w codzienność. Użytkownie sieci staje się wówczas nie tylko bezpieczniejsze, ale użyteczne. Nauczyciel wiary nie może lekceważyć tego podstawowego źródła prowadzenia misji, jaką jest bezpieczeństwo.

\section{OBECNOŚć BOga W GLOBALNEJ WiOSCE}

Konkludując, potrzeba dodać, że kluczem do edukacji medialnej jest znajomość języków mediów, co najlepiej osiąga się przez analizę i produkcję komunikatów medialnych przeprowadzanych przez samych uczniów pod kierunkiem nauczyciela. Analiza języków - kodów przekazu daje elementarną wiedzę i umiejętności do poruszania się $\mathrm{w}$ świecie często zdominowanym przez środowisko treści medialnych.

W działaniu ewangelizacyjnym wspólnoty Kościoła wadliwą jest postawa zamykania się na język mediów, tzw. syndrom „oblężonej twierdzy” tak dobrze opisany w sloganie "media kłamią" czy stereotypowe uproszczenie typu „media zawsze źle mówią o Kościele” jest nieuprawnione. Treści zaproponowanych wyżej analiz mają służyć przygotowaniu ludzi do interpretacji formy i treści przekazów medialnych, a w szczególności krytycznego spojrzenia promowanych przez media style życia i systemy wartości. Rzetelna media edukacja medialna wydaje się być istotnym panaceum na wychowanie ludzi „na

\footnotetext{
${ }^{29}$ Por. www.dzieckowsieci.pl (17.10.2017).
} 
świadomych i krytycznych konsumentów środków masowego przekazu, które w rzeczy samej są darem Boga" ${ }^{30}$. Nie możemy zapominać, że nauczyciel wiary, rodzic, misjonarz, katecheta, animator to we współczesności również edukator medialny. Nauczyciel wiary to ten, który umie kształcić u innych postawy wiary, ale też zachęca do właściwego używania i odbioru mediów. Dzisiejszy świat wymaga od niego uniwersalnej kompetencji, aby mogło dojść bez zakłóceń do spotkania człowieka z Bogiem i z drugim człowiekiem. Nie wystarczy wyłącznie używać mediów do szerzenia orędzia chrześcijańskiego. Trzeba równocześnie tworzyć człowiekowi przestrzeń wolności dla słuchania głosu Boga. Szansę taką daje edukacja do odbioru mediów.

\section{LITERATURA}

Alvarado M., Boyd-Barrett O., Media Education: an Introduction, London 1992.

Banaszkiewicz-Zygmunt E., Media. Leksykon, Warszawa 2000.

Dziennikarstwo i świat mediów, red. Z. Bauer, E. Chodziński, Kraków 2000.

Bąk A., Korzystanie z urządzeń mobilnych przez mate dzieci w Polsce. Wyniki badania ilościowego, Warszawa 2015.

Buckingham D., Media Education: Literacy, Learning and Contemporary Culture, Cambridge 2003.

Komunikacja wiary w trzecim tysiącleciu, red. S. Dziekoński, Olecko 2000.

Foley P., Bobinger U., Bóg w globalnej wiosce, tłum. M. Rodkiewicz, Kraków 2000.

Franciszek, http://pl.radiovaticana.va/news/2017/05/27/papież_do_młodych_miejcie_serce _marynarza,_odważne_i_sięgaj/1315235 (21.11.2017).

Franciszek, Przekaz w stużbie autentycznej kultury spotkania. Orędzie papieża Franciszka na XLVIII Światowy Dzień Środków Społecznego Przekazu (24.01.2014), http://w2.vatican.va/ content/francesco/pl/messages/communications/documents/papa-francesco_20140124_messaggio-comunicazioni-sociali.html (30.10. 2017).

Garcarek A., Realizacje muzycznych formatów stacji radiowych na polskim rynku medialnym, „Folia Litteraria Polonica” 17 (2012) 3, s. 182-188.

Gianatelli R., Media Education, w: La comunicazione, a cura di F. Lever, Roma 2002, s. 722-727.

Gurba K., Sieć i zycie w standby, w: Bramy prawdy i wiary. Benedykt XVI o mediach, Kraków 2016, s. 131-147.

Howard D., Mabley E., Gli strumenti dello sceneggiatore, Roma 1999.

Janus-Kwiatkowska K., Mechanizmy perswazyjne w rekalmie, http://em.pwn.pl/media/reklama. html (13.15.2004).

Królikowska A., Luszczak G., Marek Z., Dydaktyka obrazu, Kraków 2000.

Laszczak M., Psychologia przekazu reklamowego, Kraków 2000.

Masterman L., A scuola dei media, Brescia 1994.

Młodzież a Internet - raport z badań CBOS, http://www.uzaleznieniabehawioralne.pl/raporty-z-badan/mlodziez-a-internet-raport-z-badan-cbos/ (18.04.2017).

${ }^{30}$ P. Foley, U. Bobinger, Bóg w globalnej wiosce, tłum. M. Rodkiewicz, Kraków 2000, s. 23. 
Pisarek W., Nowa retoryka dziennikarska, Kraków 2011.

Pyżalski J., Klichowski M., Przybyła M., Szanse i zagrożenia w obszarze wykorzystania technologii informacyjno-komunikacyjnych (TIK), ze szczególnym uwzględnieniem aplikacji mobilnych, Poznań 2014.

Raś D., Wychowanie katechizowanych do odbioru mediów, www.katecheza.episkopat.pl/ download/ Wychow_do_odbioru_mediow.doc (28.10.2017).

Reeves B, Nass C., Media i ludzie, przeł. H. Szczerkowska, Warszawa 2000.

Strykowski W., Media i edukacja medialna w tworzeniu współczesnego społeczeństwa, w: www. kmti.uz.zgora.pl/pages/referaty/strykowski.pdf (12.05.2004).

Strykowski W., Rola mediów i edukacji medialnej w współczesnym społeczeństwie, „Chowanna” 20 (2013) nr 1, s. 111-122.

Ulfik-Jaworska I., Czy gry komputerowe moga być niebezpieczne?, http://www.katolik.pl/czy-gry-komputerowe-moga-byc-niebezpieczne-,2110,416,cz.html?s=5 (20.10.2017).

Vandendorpe Ch., Od papirusu do hipertekstu. Esej o przemianach tekstu i lektury, tłum. A. Sawisz, Warszawa 2008.

Wądołowski M., Literatura hipertekstowa - (r)ewolucja czy chaos?, http://krytyka.org/literatura-hipertekstowa-rewolucja-czy-chaos/ (3.11.2016).

Sandbothe M., Transwersalne światy medialne. Filozoficzne rozważania o Internecie, tłum. K. Krzemieniowa, w: Widzieć, myśleć, być. Technologie mediów, red. A. Gwóźdź, Kraków 2011, s. 211-221.

www.dzieckowsieci.pl (17.10.2017).

https://e-religijne.pl/pl/c/Religijne-gry-komputerowe/324 (25.10.2017).

http://mamatatatablet.pl/campaign/ (21.04.2017).

https://pk.gov.pl/aktualnosci-prokuratury-krajowej/niebezpieczna-dla-dzieci-gra-o-nazwie-niebieski-wieloryb-dotarla-do-polski.html\#.WNZcqRiBg_U (25.03.2017).

https://socialpress.pl/2017/05/22-serwisy-spolecznosciowe-z-ktorych-korzystamy-najczesciej/ (24.11.2017).

https://wydawnictwowam.pl/plyty/dla-dzieci (21.11.2017). 